\title{
Histopathological correlation of abnormal uterine bleeding in perimenopausal women
}

\author{
Deepika Verma $^{1}$, Abhyudaya Verma ${ }^{2}$ \\ ${ }^{1}$ Department of Obstetrics and Gynaecology, Sri Aurobindo Medical College and PG Institute Indore, Madhya \\ Pradesh, India \\ ${ }^{2}$ Superspeciality Endocrinology and Women Care Centre, Indore, India
}

Received: 18 May 2016

Accepted: 10 June 2016

*Correspondence:

Dr. Deepika Verma,

E-mail: drdeepikasaims@gmail.com

Copyright: ( $\odot$ the author(s), publisher and licensee Medip Academy. This is an open-access article distributed under the terms of the Creative Commons Attribution Non-Commercial License, which permits unrestricted non-commercial use, distribution, and reproduction in any medium, provided the original work is properly cited.

\section{ABSTRACT}

Background: Abnormal uterine bleeding (AUB) is one of the commonest conditions for which patients seek advice in the gynaecology outpatient department. The objective of this study was to evaluate various histopathological features in endometrial curetting's of patients above 40 years of age, complaining of abnormal uterine bleeding (AUB) and correlating them with clinical presentations.

Methods: A total of 100 endometrial curetting's were obtained by dilatation and curettage done at the department of gynecology and obstetrics, Mamatha Medical College, Khammam, Telangana, India.

Results: Out of 100 cases studied, menorrhagia (57\%) was the commonest clinical condition. Hyperplastic (48\%) change was the commonest endometrial change, followed by proliferative change (18\%). Hyperplasia when further categorized showed simple hyperplasia as the dominant sub-type. Hyperplasia was the dominant change observed in menorrhagia, polymenorrhoea, metrorrhagia, and post-menopausal bleeding.

Conclusions: Menorrhagia was the leading cause of AUB. Hyperplastic endometrium was the most common histopathological finding, with simple hyperplasia being commonest sub-type. Hyperplasia is also commonest endometrial pattern seen in patients with menorrhagia. AUB occurring at perimenopausal age is alarming and needs thorough evaluation, as it could be the only clinical manifestation of endometrial cancer, as was noticed in this study.

Keywords: Histopathology, AUB, Endometrium, Perimenopausal women

\section{INTRODUCTION}

Abnormal uterine bleeding (AUB) is one of the commonest conditions for which patients seek advice in the gynaecology outpatient department. AUB may be defined as changes in frequency of menstruation, duration of flow or amount of blood loss. ${ }^{1}$ Abnormal uterine bleeding can be caused by well-defined organic pathologic conditions, such as chronic endometritis, endometrial polyp, sub mucosal leiomyoma's, or endometrial neoplasms, the largest single group encompasses functional disturbances, referred to as dysfunctional uterine bleeding (DUB). ${ }^{2}$ Abnormal uterine bleeding is the main reason women are referred to gynaecologists and accounts for two thirds of all hysterectomies. ${ }^{3}$

DUB has great variation in the endometrial patterns and its management entirely depends upon the type of endometrium. Thus, histopathological study of endometrium plays an important role in its treatment. ${ }^{4}$ Similarly, endometrial sampling could be effectively used as the first diagnostic step in AUB, although at times, its interpretation could be quite challenging to the practicing pathologists. $^{2}$ 
Hence, this study was aimed to evaluate various pathological features in endometrial curetting of patients complaining of menstrual irregularities and correlating them with clinical presentations and evaluation of histopathology of endometrium for identifying the endometrial causes of AUB.

\section{METHODS}

This is a prospective study conducted at department of obstetrics and gynaecology, Mamatha Medical College, Khammam from November 2004 to June 2006. Study was initiated after approval of institutional ethical committee. Total 100 perimenopausal women, aged above 40 years with abnormal uterine bleeding were included in the study. Pregnancy related normal and abnormal bleeding was excluded from the study. Data was collected by using predesigned proforma for recording their age, parity, menstrual symptoms and associated symptoms for clinical evaluation. These women underwent endometrial sampling by curettage or fractional curettage and were submitted for histopathological examination. Descriptive statistics like percentages are used for analysis. The comparison was made between these findings and conclusions were drawn after comparing and discussing with similar type of the work carried out by other authors.

\section{RESULTS}

Out of 100 cases studied, menorrhagia (57\%) was the commonest clinical condition. (Figure 1) Hyperplastic (48\%) change was the commonest endometrial change, followed by proliferative change (18\%). Endometrial carcinoma was detected in $5 \%$ of cases (Table 1). Hyperplasia when further categorised, showed simple hyperplasia as the dominant sub-type (Table 2). Hyperplasia was the dominant change observed in menorrhagia, polymenorrhoea, metrorrhagia, and postmenopausal bleeding (Table 3).

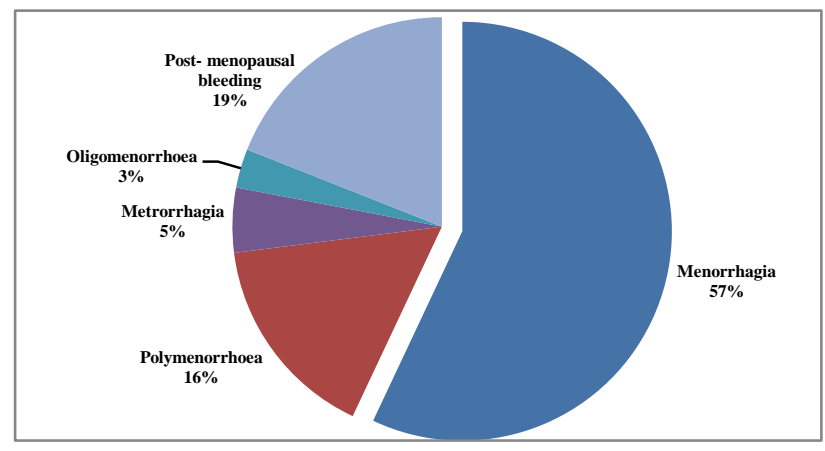

Figure 1: Distribution of cases according to type of abnormal uterine bleeding.

Table 1: Distribution of cases according to endometrial patterns.

\begin{tabular}{|ll|}
\hline Endometrial changes & Cases (percentage) \\
\hline Hyperplasia & $48(48 \%)$ \\
\hline Proliferative phase & $18(18 \%)$ \\
\hline Endometritis & $17(17 \%)$ \\
\hline Atropic & $7(7 \%)$ \\
\hline Polyp & $5(5 \%)$ \\
\hline Carcinomas & $5(5 \%)$ \\
\hline Total & $\mathbf{1 0 0}(\mathbf{1 0 0} \%)$ \\
\hline
\end{tabular}

Table 2: Incidence of various types of hyperplasia.

\begin{tabular}{|ll|}
\hline Types of hyperplasia & Cases (percentage) \\
\hline Simple hyperplasia & $24(50 \%)$ \\
\hline Complex hyperplasia & $12(25 \%)$ \\
\hline Cystic glandular & $3(6.25 \%)$ \\
\hline Atypical hyperplasia & $9(18.75 \%)$ \\
\hline Total & $\mathbf{4 8 ( 1 0 0 \% )}$ \\
\hline
\end{tabular}

Table 3: Endometrial pattern in various types of abnormal uterine bleeding.

\begin{tabular}{|c|c|c|c|c|c|c|c|}
\hline $\begin{array}{l}\text { Bleeding } \\
\text { complication }\end{array}$ & $\begin{array}{l}\text { Proliferative } \\
\text { phase }\end{array}$ & Hyperplasia & Carcinoma & Atrophy & Endometritis & Polyp & Cases \\
\hline Menorrhagia & $12(21 \%)$ & $30(52.6 \%)$ & $1(1.7 \%)$ & $4(7 \%)$ & $9(15.7 \%)$ & $2(3.5 \%)$ & $57(100 \%)$ \\
\hline $\begin{array}{l}\text { Poly- } \\
\text { menorrhoea }\end{array}$ & $2(12.5 \%)$ & $8(50 \%)$ & $1(6.2 \%)$ & $1(6.2 \%)$ & $4(25 \%)$ & - & $16(100 \%)$ \\
\hline Metrorrhagia & $1(20 \%)$ & $4(80 \%)$ & $1(20 \%)$ & - & - & - & $5(100 \%)$ \\
\hline $\begin{array}{l}\text { Oligo- } \\
\text { menorrhoea }\end{array}$ & $1(33.3 \%)$ & - & - & - & $3(66.6 \%)$ & - & $3(100 \%)$ \\
\hline $\begin{array}{l}\text { Post-menopausal } \\
\text { bleeding }\end{array}$ & $2(10.5 \%)$ & $6(31.5 \%)$ & $2(10.5 \%)$ & $2(10.5 \%)$ & $1(5.2 \%)$ & $3(15.7 \%)$ & $19(100 \%)$ \\
\hline
\end{tabular}

\section{DISCUSSION}

Abnormal uterine bleeding needs an evaluation with a combination of the following: history, physical examination, ultrasound and histopathological evaluation. ${ }^{5}$ Hysteroscopically directed biopsies; the trend of current days was not done in present study because of non-availability of this facility. The literature 
revealed that $50 \%$ of hysterectomy specimens are free of histopathological abnormalities. ${ }^{6}$ Hence it is not surprising that endometrial sampling by dilation and curettage (D and C) is so commonly used.

In this study, the most common clinical presentation was menorrhagia (57\%), followed by post-menopausal bleeding $(19 \%)$, and polymenorrhoea $(16 \%)$, which is concurrent with finding of Jairapuri $\mathrm{ZS}$ et al. ${ }^{7}$ The incidence of menorrhagia was less as compared to $69.65 \%$ quoted by Yusuf et al but more than $41 \%$ quoted by Moghal. ${ }^{8,9}$

Hyperplasia (48\%) was commonest endometrial pathology diagnosed which is comparable with study by Sutherland AM, while proliferative pattern was observed to be most common by Ghani NA et al. ${ }^{2,10}$ Simple hyperplasia $(50 \%)$ was the common histopathological variant of hyperplasia, which is concurrent with finding of Gupta A et al where simple hyperplasia was the common abnormal endometrial pattern. ${ }^{5}$ Hyperplasia was also common endometrial pattern in clinical conditions of menorrhagia, metrorrhagia, polymenorrhoea and postmenopausal bleeding.

In the present study, $5(5 \%)$ cases were diagnosed as carcinoma endometrium, which were innocuous otherwise. In study by Shrestha $\mathrm{S}$ et al malignancy was most commonly found in post-menopausal age group patients. ${ }^{11}$ Endometrial cancer develops through preliminary stages of endometrial hyperplasia. Abnormal uterine bleeding in perimenopausal women is associated with endometrial carcinoma in $10 \%$ patients, so evaluation of women's risk factors for endometrial hyperplasia or carcinoma is recommended. ${ }^{3,5}$ Thus, correct diagnosis is crucial to plan an optimal treatment and to prevent endometrial cancer development. ${ }^{12}$

\section{CONCLUSION}

The most common clinical presentation in AUB is menorrhagia followed by postmenopausal bleeding. Hyperplastic endometrium was the most common histopathological finding, with simple hyperplasia being commonest sub-type. Hyperplasia is also commonest endometrial pattern seen in patients with menorrhagia. AUB occurring at perimenopausal age is alarming and needs thorough evaluation, as it could be the only clinical manifestation of endometrial cancer, as was noticed in this study. This study also reconfirmed that dilatation and curettage is an appropriate approach with a good diagnostic yield.
Funding: No funding sources

Conflict of interest: None declared

Ethical approval: The study was approved by the Institutional Ethics Committee

\section{REFERENCES}

1. Munro MG. Abnormal uterine bleeding in the reproductive years: pathogenesis and clinical investigations. J Am Assoc Gynecol lapros. 1999;6:393-416.

2. Ghani NA, Razak AA, Abdullah EM. Abnormal uterine bleeding: a histopathological study. World Research Journal of Clinical Pathology. 2012:1(1);06-08.

3. Telner DE, Jakubovicz D. Approach to diagnosis and management of abnormal uterine bleeding. Can Family Physician. 2007;53:58-64.

4. Annigeri C, Katti T, Karaddi S. Histopathological spectrum of endometrium in dysfuctional uterine bleeding with respect to age, parity and bleeding pattern. BMR Med. 2014;1:1-12.

5. Gupta A, Rathore AM, Manaktala U, Rudingwa P. Evaluation and histopathological correlation of abnormal uterine bleeding in perimenopausal women. Int J Biomed Adv Res. 2013;4(8):509-13.

6. Oehler MK, Rees MC. Menorrhagia: an update. Acta Obstet Gynecol Scand. 2003;82:405-22.

7. Jairapuri ZS, Rana S, Jeteley S. Atypical uterine bleeding-histopathological audit of endometrium: a study of 638 cases. Al Ameen J Med Sci. 2013;6(1):21-8.

8. Yusuf NW, Nadeem R, Yusuf AW, Rahman R. Dysfunctional uterine bleeding. A retrospective clinic pathological study over 2 years. Pak J Obstet Gynaecol. 1996;9:27-30.

9. Moghal N. Diagnostic value of endometrial curettage in abnormal uterine bleeding: a histopathological study. J Pak Med Assoc. 1997;47:295-9.

10. Sutherland AM. Functional uterine haemorrhage: a critical review of the literature since 1938. Glasgow Med J. 1949;30:1-28.

11. Shrestha S, Sigdel B. Study of endometrial status of patients with abnormal uterine bleeding in patan hospital. J Coll Med Sci. 2013;9(2):20-4.

12. Ørbo A, Arnes M, Hancke C, Vereide A, Pettersen I, Larsen K. Treatment results of endometrial hyperplasia after prospective D-score classification: a follow-up study comparing effect of LNG-IUD and oral progestins versus observation only. Gynecol Oncol. 2008;111(1):68-73.

Cite this article as: Verma D, Verma A.

Histopathological correlation of abnormal uterine bleeding in perimenopausal women. Int J Reprod Contracept Obstet Gynecol 2016;5:2343-5. 